homogeneous membranes are formed by the excavation of the cytoblasts, I believe that he has not observed all the stages and transitions of the cytoblasts into starch; for he does not notice the formation of the starch from the excavated cytoblast. The formation of a homogeneous membrane (membrane-substance) from the external layers of the cytoblast appears to be a very peculiar process, which will hereafter explain how it is that this membrane is not formed round a perfect cytoblast, and the transition of the latter into another state of aggregation (starch).

Still we cannot explain the whole process of the formation of starch throughout the organic kingdom from these investigations, which may be readily made in the manner stated. The above isolated instance is insufficient; I therefore refrain from any further comparison of the separate stages of the starch-formation. However, this example, especially as it may be so readily observed, will constitute a sure starting-point from which we may trace the formation of starch generally.

XI.-Notice of Spiders captured by Professor Potter in Canada, with descriptions of such Species as appear to be new to science. By John Blackwall, F.L.S.

[Continued from p. 44.]

Genus Tegenaria, Walck.

19. Tegenaria civilis.

Tegenaria civilis, Walck. Hist. Nat. des Insect. Apt. t. 2. p. 7; Koch, Die Arachn. (Fortsetzung des Hahn'schen Werkes), B. 8. p. 37. t. 264. fig. 618,619 .

Agelena civilis, Sundevall, Vet. Acad. Handl. 1831.p. 127. Araneus subflavus, Lister, De Aran. p. 59. tit. xvii. fig. 17.

\title{
Family Therididde.
}

\section{Genus Theridion, Walck.}

\section{Theridion quadripunctatum.}

Theridion quadripunctatum, Walck. Hist. Nat. des Insect. Apt. t. 2. p. 290 ; Sundevall, Vet. Acad. Handl. 1831.p. 118; Hahn, Die Arachn. B. 1. p. 78. tab. 20. fig. 58.

Eucharia bipunctata, Koch, Uebersicht des Arachnidensystems, Erstes Heft, p. 7. tab. 1. fig. 13.

Araneus pullus, Lister, De Aran. p. 49. tit. xi. fig. 11. 


\section{Theridion sisyphum.}

Theridion sisyphum, Walck. Hist. Nat. des Insect. Apt. t. 2. p. 298 ; Latr. Genera Crust. et Insect. t. 1. p. 97; Hahn, Die Arachn. B. 2. p. 47. tab. 58. fig. 132.

Theridion lunatum, Sundevall, Vet. Acad. Handl. 1831.p.111; Koch, Die Arachn. B. 8. p. 74. tab. 273. fig. 645.

Araneus rufus, Lister, De Aran. p. 53. tit. xiv. fig. 14.

\section{Genus Pholcus, Walck.}

\section{Pholcus phalangioides.}

Pholcus phalangioides, Walck. Hist. Nat. des Insect. Apt.t. 1. p. 652 ; Latr. Genera Crust. et Insect. t. 1. p. 99 ; Hahn, Die Arachn. B. 2. p. 34. tab. 50. fig. 119; Blackw. Linn. Trans. vol. xix. p. 125.

The spider referred to by Mr. Jesse in his 'Scenes and Tales of Country' Life,' pp. 202 and 203, as remarkable for the rapidity of its vibratory motions when disturbed, is, I have no doubt, Pholcus phalangioides, which frequents ancient buildings in the south of England, and, like Epëira diadema, Theridion quadripunctatum and some other species, has the habit of violently agitating itself when anything suddenly touches its lines. This vibratory motion, which in the case of Pholcus phalangioides appears to acquire its maximum of velocity, is produced by the partial contraction and extension of the joints of the legs in quick succession, as I have ascertained by occasioning specimens of Epëira diadema to continue the action till it became so slow, in consequence of the fatigue experienced by the animals, that there was no difficulty in determining the manner in which it is effected. This singular proceeding is evidently intended by the spider to communicate motion to its snare and thus to cause the struggles of any insect entangled in it, by which means it is directed with certainty to its victim.

I may here remark that the large spider alluded to in the same publication, p. 339, as peculiar to Hampton Court, and there named the "Cardinal," most probably is the Tegenaria domestica of arachnologists.

\section{Family EPËIRID必.}

\section{Genus EPËIRA, Walck.}

\section{Epëira affinis.}

Length of the female $\frac{7}{12}$ ths of an inch ; length of the cephalothorax $\frac{11}{4} \frac{1}{8}$; breadth $\frac{3}{16}$; breadth of the abdomen $\frac{1}{5}$; length of an anterior leg $\frac{9}{10}$; length of a leg of the third pair $\frac{23}{4}$.

Cephalo-thorax compressed before, moderately convex, with a large indentation in the medial line of the posterior region; it is 
of a dark brown colour and is provided with hoary hairs, which form a line extending along each lateral margin, and a curved transverse one in front, passing between the two intermediate pairs of eyes. Mandibles powerful, conical, vertical, armed with two rows of teeth on the inner surface: maxillæ short, strong, enlarged and rounded at the extremity : lip semicircular, slightly pointed: sternum heart-shaped, with small eminences on the margins opposite to the articulation of the legs: these parts are of a dark brown colour, the extremities of the maxillæ and lip being yellowish brown. Legs long and robust, provided with hairs and spines ; they are of a yellow-brown colour, marked with dark brown annuli ; each femur has a broad annulus at its extremity, that of the anterior ones extending over half the joint; first pair of legs the longest, then the second, third pair the shortest. The palpi resemble the legs in colour. Eyes disposed in two transverse rows on the anterior part of the cephalo-thorax ; the four intermediate ones, which are seated on a prominence, form a square nearly, the eyes of the anterior pair being rather more distant from each other than those of the posterior pair, and the largest of the eight; the eyes of each lateral pair are placed obliquely on a tubercle,but are not contiguous. Abdomen oviform, thinly clad with hairs, convex above, projecting over the base of the cephalo-thorax; the upper part is yellowish brown, with a large, dark brown, festooned band, which tapers to the spinners, extending along the middle; the anterior part of this band comprises a yellowish brown isosceles triangle including a dark brown triangle of the same form, both having their vertices directed forwards ; the posterior part of the band comprises a yellowish brown cross, the longitudinal portion of which tapers towards the spinners and includes a dark brown line, extending along the middle, which is broadest near its anterior extremity; the transverse portion of the cross is somewhat curved, and its extremities usually break the continuity of the large, dark brown festooned band, whose posterior part is marked with some yellowish brown transverse lines; sides yellowish brown, with a broad, longitudinal, dark brown band, dentated at its superior margin, and mottled with yellowish brown; middle of the under part brownish black, with a curved yellowish line on each side, which does not extend to the spinners. The sexual organs are reddish brown, and have a cylindrical membranous process directed backwards, connected with their anterior margin. Plates of the spiracles brown.

The colours of the sexes are very similar, but the male is smaller and slenderer than the female and its legs are longer, an anterior one measuring 1 inch and $\frac{5}{2}$ ths. The palpi are short; the anterior extremity of the cubital joint is provided on the 
upper side with two long bristles directed forwards; the radial joint is larger than the cubital, and projects a strong process from its outer side, which is gibbous above near its base, and is amply provided with long hairs; the digital joint is somewhat oval, with a process at its superior extremity curved outwards; it is convex and hairy externally, concave within, comprising the palpal organs, which are highly developed, complicated in structure, with a large, erect, bifid process at their upper part having a projection near the extremity and a gibbosity near the base of the larger limb on the inner side; lower down is a prominent, depressed, yellowish brown process, which is enlarged and rounded at its extremity; contiguous to this, on the inner side, are the somewhat pointed terminations of three prominent processes, the largest of which curves round the extremity of the palpal organs, whose colour is reddish brown with yellowish brown intermixed. The convex sides of the digital joints are directed towards each other.

Epëira affinis, though very closely related to Epëira apoclisa, may be distinguished from it by its superior size, by differences in external organization, and by the legs of the male considerably exceeding in length those of the female. Lister, it is true, in comparing the sexes of Epëira apoclisa, remarks of the male, that "et pedes et tela longiora;" De Aran. p. 37. Walckenaer also states that "le mâle a les pattes beaucoup plus longues ;" Nat. Hist. des Insect. Apt. t. 2. p. 63 ; but as regards every specimen, whether British or continental, which I have had an opportunity of measuring, the reverse has invariably proved to be the fact.

Among the more obvious structural differences observable in the organs of reproduction in males of these species are the following. The erect, bifid process at the upper part of those organs in Epëira apoclisa is proportionably longer and slenderer, is without the projection near the extremity of the larger limb on the inner side, and the gibbosity near its base is much smaller and situated lower ; there are, besides, the extremities of two processes only contiguous to the inner side of the prominent, yellowish brown process, the larger of which curves round the lower part of the sexual organs, and terminates in a slender, finelypointed spine.

Whether the opinion entertained by Koch, that the Epëira described by him under the specific name of foliata* differs from Epeira apoclisa, and is identical with the American spider at present regarded by Baron Walckenaer as a mere variety of that speciest, be well-founded or not, I do not possess the means of

* Die Arachn. B. 11.p. 119. tab. 387. fig. 920, 921.

$\uparrow$ Hist. Nat. des Insect. Apt. t. 2. p. 62. 
satisfying myself; but it is evidently distinct from Epëira affinis, many varieties of which were included in the Canadian spiders collected by Professor Potter.

\section{Epëira approximata.}

Length of the female $\frac{9}{16}$ ths of an inch ; length of the cephalothorax $\frac{7}{24}$; breadth $\frac{1}{4} \frac{1}{8}$; breadth of the abdomen $\frac{7}{24}$; length of an anterior leg $\frac{9}{10}$; length of a leg of the third pair $\frac{9}{16}$.

Cephalo-thorax large, compressed before, truncated in front, moderately convex, glossy, with furrows on the sides diverging towards the lateral margins, and a large indentation in the medial line of the posterior region; its colour is dull yellow, the anterior part, which is sparingly covered with hoary hairs, being tinged with red. Eyes disposed in two transverse rows on the anterior part of the cephalo-thorax; the four intermediate ones are seated on a prominence and form a square nearly, the eyes of the anterior pair, which are the largest of the eight, being rather more distant from each other than those of the posterior pair ; the eyes of each lateral pair are placed obliquely on a tubercle, but are not contiguous. Mandibles powerful, conical, vertical, and armed with two rows of teeth on the inner surface; their colour is pale red-brown, the fang being dark reddish brown. Maxillæ short, strong, enlarged and rounded at the extremity: lip semicircular and slightly pointed: sternum heart-shaped, with eminences on the margins opposite to the articulation of the legs : these parts are dark red-brown, with the exception of the extremities of the maxillæ and lip, which are yellowish brown. Legs robust, provided with hairs and spines ; first pair the longest, then the second, third pair the shortest; they are of a dull yellow colour, with red--brown annuli at the joints, the tarsi being reddish brown. The palpi are dull yellow, except the extremity of the digital joint, which is reddish brown. Abdomen oviform, thinly clad with hoary hairs, convex above, projecting greatly over the base of the cephalo-thorax; the upper part is yellow, with four very conspicuous, sunken, brown spots forming a trapezoid whose narrowest side is before; posterior part and sides faintly tinged with brown; middle of the under part brownish black, with a curved, yellow line on each side, whose extremity does not extend to the spinners. Connected with the superior margin of the sexual organs is a long, striated, prominent membranous process, curved downwards at its base and recurved at its extremity. Spinners and plates of the spiracles dark brown.

In immature individuals of this species, which is nearly allied to Epëira vulpecula (see Baron Walckenaer's Hist. Nat. des Insect. Apt. t. 2. p. 69), the faint outline of a festooned band may be 
traced extending along the middle of the upper part of the abdomen.

\section{Epëira canadensis.}

Length of the female $\frac{1}{5}$ th of an inch; length of the cephalothorax $\frac{1}{12}$; breadth $\frac{1}{16}$; breadth of the abdomen $\frac{1}{8}$; length of an anterior leg $\frac{7}{2} 4$; length of a leg of the third pair $\frac{1}{7}$.

Cephalo-thorax rather small, compressed before, somewhat pointed in front, very convex, with a large, longitudinal indentation in the middle of the posterior region; it is of a dull yellowish brown colour, and the anterior part, which has a brown spot on each side of the medial line, is sparin gly covered with hoary hairs. Eyes disposed in two transverse rows on the anterior part of the cephalo-thorax ; the four intermediate ones are seated on an obtuse prominence and form a square, those of the posterior pair, which are placed on black spots, being the largest of the eight; the eyes of each lateral pair are the smallest, and are placed on a minute tubercle, but neither obliquely nor contiguously. Mandibles powerful, conical, vertical, rather long, somewhat divergent at the extremities, and armed with two rows of teeth on the inner surface : maxillæ short, strong, enlarged and rounded at the extremity : lip semicircular and pointed at the apex : these parts are dull yellowish brown. Sternum heart-shaped, brown. Legs moderately long, slender, provided with hairs and spines; first pair the longest, then the second, third pair the shortest; they are of a dull yellowish brown colour, marked with obscure brown annuli, the annulus at the extremity of each femur being the largest and most conspicuous. Palpi dull yellowish brown. Abdomen somewhat triangular, with an obtuse prominence above the spinners ; it is thinly clad with hairs, convex above, projecting over the base of the cephalo-thorax ; its general colour is dull yellowish brown, the upper part having a large, dark brown, festooned band extending along the middle and tapering to the spinners; this band comprises several transverse dull yellowish brown bars, the anterior one, which is much the largest, being crescent-shaped with its convexity directed forwards.

The specimen from which the above description was made had not attained to maturity, as the organs of reproduction were not fully developed.

\section{Genus Tetragnatha, Latr.}

\section{Tetragnatha armigera.}

Length of the female, not including the mandibles, $\frac{2}{5}$ ths of an inch ; including the rnandibles $\frac{1}{2}$; length of the cephalo-thorax $\frac{3}{20}$; breadth $\frac{1}{12}$; breadth of the abdomen $\frac{1}{10}$; length of an anterior leg $1 \frac{1}{5}$; length of a leg of the third pair $\frac{2}{5}$. 
Mandibles nearly cylindrical, very long and prominent, widely divergent at the extremities, which are armed with a long, slightly curved dark brown fang, having a small, obtuse protuberance at its base on the upper side; on their inner surface are two rows of teeth, the outer one consisting of twelve and the inner one of eight ; they have, besides, seven strong tooth-like processes at their extremity surrounding the base of the fang: maxillæ long, straight, enlarged at the extremity, which is prominent and somewhat angular on the outer side: these parts are yellowish brown. Lip semicircular and dark brown, the apex, which is prominent, being yellowish brown. Sternum of an elongated heart-shape and brown colour. Cephalo-thorax somewhat oval, slightly compressed before, broadly rounded in front, with a large circular indentation in the medial line of the posterior region; it is of a brown colour with rays of a deeper shade diverging from the medial indentation to the margins. Eyes disposed on black spots in two transverse nearly parallel rows on the anterior part of the cephalo-thorax; the anterior intermediate pair, with each lateral pair, is seated on a prominence, the anterior eye of the latter being the smallest of the eight. Legs long, slender, provided with hairs and a few fine spines; they are of a pale brown colour; first pair the longest, then the second, third pair the shortest. Palpi very slender and yellowish brown; the cubital joint is the shortest and after that the axillary joint. Abdomen long, somewhat cylindrical, enlarged at its anterior and tapering to its posterior part; along the middle of the upper part extends a large, festooned brown band whose margins are the darkest ; in the medial line of this band are numerous, minute, whitish spots, and four small indentations, forming an elongated trapezoid, whose anterior side is the shortest, occur on the part which is enlarged; sides dull yellowish brown, comprising an obscure, irregular, longitudinal brown band; under part dull yellowish brown, with a dark brown band in the middle tapering to the spinners, at the base of which, on each side, is a whitish spot. Spinners and plates of the spiracles reddish brown.

\section{XII.-On the British Cetacea. By J. E. Gray, Esq., F.R.S.}

Having occasion lately to examine the various species of Cetacea in the British Museum and other collections and the various authorities for the species, I am induced to send you the following list containing some additions to our fauna. It would appear as though modern writers on this part of our fauna had not taken the trouble to examine for themselves the authority on which the spe-

- cies have been determined. Dr. Fleming, in his 'British Ani- 


\section{$2 \mathrm{BHL}$ Biodiversity Heritage Library}

Blackwall, John. 1846. "XI.-Notice of spiders captured by Professor Potter in Canada, with descriptions of such species as appear to be new to science." The Annals and magazine of natural history; zoology, botany, and geology 17, 76-82. https://doi.org/10.1080/037454809495559.

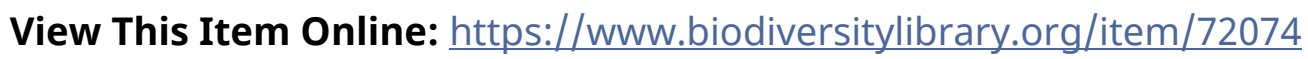

DOI: https://doi.org/10.1080/037454809495559

Permalink: https://www.biodiversitylibrary.org/partpdf/60740

\section{Holding Institution}

University of Toronto - Gerstein Science Information Centre

\section{Sponsored by}

University of Toronto

\section{Copyright \& Reuse}

Copyright Status: NOT_IN_COPYRIGHT

This document was created from content at the Biodiversity Heritage Library, the world's largest open access digital library for biodiversity literature and archives. Visit BHL at https://www.biodiversitylibrary.org. 